\title{
Awareness of pinworm disease among students of university
}

\begin{abstract}
The objective of present study was the awareness of pinworm disease among students of university. A pinworm infection is a notable amongst the most widely known kinds of human intestinal worm infection. Pinworms are little, smart worms. ${ }^{1}$ They're white in color and not exactly a $1 / 2$ inch long. Pinworm diseases are also called enter biases or oxyuriases. ${ }^{2}$ From the survey we come to know that mostly people know about pinworm disease. It's a parasitic disease and low amount of people got up with this disease. It not spread by contacts or blood transfusions. It can be cured by medicines. ${ }^{3}$
\end{abstract}

Keywords: pinworm, socioeconomic level, diagnosis, polluted water, drink or your fingers, socioeconomical level, enterobiases or oxyuriases, infecting clothing, sheet, food, human intestinal worm infection, little, smart worms
Volume 3 Issue I - 2019

\author{
Muhammad Imran Qadir, Usman Riaz \\ Institute of Molecular Biology and Biotechnology, Bahauddin \\ Zakariya University, Pakistan
}

Correspondence: Usman Riaz, Institute of Molecular Biology and Biotechnology, Bahauddin Zakariya University, Chak No 100 Wb Garha More Teshsil Mailsi District Vehari, Multan, Pakistan, Tel+923016747788, Email Usmanriazp@gmail.com

Received: December 06, 2018 | Published: January 08, 2019

\section{Introduction}

A pinworm infection is a standout amongst the most widely known kinds of human intestinal worm diseases. Pinworms are little, thin worms. They're white in color and not exactly a $1 / 2$ inch long. Pinworm diseases are also called enterobiases or oxyuriases. Pinworm infection reasons itching round the anal area which primes to trouble sleep and restiveness. A pinworm infection happens worldwide and distresses persons of all ages and socioeconomical level. ${ }^{4} \mathrm{~A}$ pinworms infection habitually occurs in more than one person in home and officialinstitute settings. Pinworm infection is banquet by the fecal-route, which is by the transfers of infectious pinworms egg from the anal area to someone mouth, which ever straight by hand or circuitously finished infecting clothing, sheet, food or anotherarticle. Burning during the night in a children perineal area powerfully proposed pinworm infection. Diagnosis is done by recognizing the worms or its eggs. Worms can be perceived on the skin near anal area or on under things, night clothes, or sheets about 2 to 3 hours after dwindling sleep. A positive dealing for pinworm infections is medicine, but reinjection is believable. Genuine complexities and long-haul well being impacts are rare. Accidentally engulfing pinworm eggs causes a pinworm infection. The infinitesimal eggs can reach to your mouth by polluted water, drink or your fingers. Once gulped, the eggs bring forth in the intestine and develop into mature worms inside in fourteen days. Indicator cleanliness is utmost tactual resources of inhibition. The diseased person family associates and wardens must preserve. Uncertainty pinworm infections continue to happen; the basis of the contamination must be required and preserved. Friends, school-mates, nearby friends outdoor the household and family associates must measure conceivable foundations of infections. Respectively diseased person must obtain the suggested two dose treatments. The objective of current study is the awareness of pinworm infection among the students of university. ${ }^{5}$

\section{Material and methods}

Questionnaire to evaluate awareness about pinworm and Questionnaire to evaluate inspection about occurrence of pinworm. Questionnaire to evaluate inspection about the handling of pinworm, Questionnaire to evaluate inspection about spreading of pinworm. ${ }^{6,7}$

The type of disease pinworm is Yes No

1. Is it viral?

\section{Is it bacterial? \\ 3. Is it fungal? \\ 4. Is it genetic? \\ 5. Is it metabolic?}

\begin{tabular}{l}
\hline Ever hurt from Pinworm Yes No \\
\hline 1. Are You affected by infection \\
2. Your family member affected by infection \\
3. Your relative affected by infection \\
4. Your neighbor affected by infection \\
5. Your friend affected by infection \\
\hline
\end{tabular}

Pinworm is spread by Yes No

1. Through Contacts or blood-giving

2. From parents to child's

\begin{tabular}{ll}
\hline Pinworm may handle by & Yes \\
\hline 1. Medicines \\
2. Surgery \\
3. No need of treatment \\
\hline
\end{tabular}

\section{Results and discussion}

From the Table 1 we concluded that mostly people said that pinworm is a bacterial disease and some of them said that its viral disease. ${ }^{8}$ All people said that it's not genetic disease. From the Table 2 we noted that it is less common among the university students. Mostly people said that their relatives got up with this disease and mostly they never suffered from pinworm disease. From the Table 3 all people said it is not spread by any contact or blood transfusion and they also know that its not genetic disease. From the Table 4 we noted that almost all people said it can be cured by medicines easily and more than half also said that there is no need for any treatment. ${ }^{9,10}$

Table 1 Questionnaire to evaluate awareness about pinworm

\begin{tabular}{lllllll}
\hline Pinworm is a & Male & \multicolumn{3}{l}{ Female } & Total \\
\hline & Yes & No & Yes & No & Yes & No \\
1. Viral disease & $12 \%$ & $88 \%$ & $16 \%$ & $84 \%$ & $14 \%$ & $86 \%$ \\
2. Bacterial disease & $82 \%$ & $18 \%$ & $85 \%$ & $15 \%$ & $84 \%$ & $16 \%$ \\
3. Fungal disease & $9 \%$ & $81 \%$ & $8 \%$ & $92 \%$ & $9 \%$ & $91 \%$ \\
4. Genetic disease & $0 \%$ & $100 \%$ & $0 \%$ & $100 \%$ & $0 \%$ & $100 \%$ \\
5. Metabolic disease & $0 \%$ & $100 \%$ & $0 \%$ & $100 \%$ & $0 \%$ & $100 \%$
\end{tabular}


Table 2 Questionnaire to evaluate views about commonness of pinworm

\begin{tabular}{lllllll}
\hline $\begin{array}{l}\text { Ever suffered } \\
\text { from pinworm }\end{array}$ & Male & \multicolumn{3}{c}{ Female } & \multicolumn{3}{c}{ Total } \\
\hline & yes & no & yes & no & yes & No \\
\hline you & $6 \%$ & $94 \%$ & $5 \%$ & $95 \%$ & $6 \%$ & $94 \%$ \\
your family & $3 \%$ & $97 \%$ & $4 \%$ & $96 \%$ & $3 \%$ & $97 \%$ \\
your relatives & $12 \%$ & $88 \%$ & $8 \%$ & $92 \%$ & $10 \%$ & $90 \%$ \\
your neighbors & $9 \%$ & $91 \%$ & $7 \%$ & $93 \%$ & $8 \%$ & $92 \%$ \\
your friends & $12 \%$ & $88 \%$ & $1 \%$ & $99 \%$ & $5 \%$ & $95 \%$ \\
\hline
\end{tabular}

Table 3 Questionnaire to evaluate views about transmission of pinworm

\begin{tabular}{lcccccc}
\hline $\begin{array}{l}\text { Pinworm } \\
\text { Transmitted by }\end{array}$ & \multicolumn{2}{l}{ Male } & \multicolumn{2}{l}{ Female } & \multicolumn{2}{l}{ Total } \\
\hline & yes & no & yes & no & yes & no \\
$\begin{array}{l}\text { contact or blood } \\
\text { transfusion }\end{array}$ & $0 \%$ & $100 \%$ & $0 \%$ & $100 \%$ & $0 \%$ & $100 \%$ \\
$\begin{array}{l}\text { from parents to off } \\
\text { spring }\end{array}$ & $0 \%$ & $100 \%$ & $0 \%$ & $100 \%$ & $0 \%$ & $100 \%$ \\
\hline
\end{tabular}

Table 4 Questionnaire to evaluate views about the treatment of pinworm

\begin{tabular}{lllllll}
\hline $\begin{array}{l}\text { Pinworm may } \\
\text { Treated by }\end{array}$ & Male & & Female & \multicolumn{3}{c}{ Total } \\
\hline & yes & no & yes & no & yes & no \\
\hline Medicines & $97 \%$ & $3 \%$ & $96 \%$ & $4 \%$ & $97 \%$ & $3 \%$ \\
$\begin{array}{l}\text { Surgery } \\
\begin{array}{l}\text { No need for any } \\
\text { treatment }\end{array}\end{array}$ & $79 \%$ & $100 \%$ & $0 \%$ & $100 \%$ & $0 \%$ & $100 \%$ \\
\hline
\end{tabular}

\section{Conclusion}

We concluded from the present study that mostly people know that pinworm is a bacterial disease parasitic disease and less common among the university students. It is not a genetic disease and not spread by blood transfusion and can be cured by medicines.

\section{Acknowledgments}

None.

\section{Conflicts of interest}

The author declares there is no conflict of interest.

\section{References}

1. Kucik CJ, Martin GL, Sortor BV. Common intestinal parasites. American family physician. 2004;69(5):1.

2. Qadir MI, Noor A. Anemias. Rare \& Uncommon Diseases. Cambridge Scholars Publishing. Newcastle, England. 2018.

3. Qadir MI, Javid A. Awareness about Crohn's Disease in biotechnology students. GloAdv Res J Med Medical Sci. 2018;7(3):62-64.

4. Qadir MI, Saleem A. Awareness about ischemic heart disease in university biotechnology students. Glo Adv Res J Med Medical Sci. 2018;7(3):059-061.

5. Qadir MI, Ishfaq S. Awareness about hypertension in biology students. Int J Mod Pharma Res. 2018;7(2):8-10.

6. Qadir MI, Mehwish. Awareness about psoriasis disease. Int $J$ Mod Pharma Res. 2018;7(2):17-18.

7. Qadir MI, Shahzad R. Awareness about obesity in postgraduate students of biotechnology. Int J Mod Pharma Res. 2018;7(2):14-16.

8. Qadir MI, Rizvi M. Awareness about thalassemia in post graduate students. MOJ Immunology. 2018;2(1):14-16.

9. QadirMI, Ghalia BA.Awareness surveyaboutcolorectalcancerinstudents of M. Phil Biotechnology at BahauddinZakariya University, Multan, Pakistan. Nov Appro in Can Study. 2018;1(3):NACS.000514.2018.

10. Qadir MI, Saba G. Awareness about intestinal cancer in university student. Nov Appro in Can Study. 2018;1(3):NACS.000515.2018. 